\title{
Performance of lambs and the incidence of staggers and heat stress on two perennial ryegrass cultivars over three summers in the Manawatu
}

\author{
S.J. BLUETT ${ }^{1}$, J. HODGSON ${ }^{1}$, P.D. KEMP ${ }^{1}$ and T.N. BARRY ${ }^{2}$ \\ ${ }^{1}$ Institute of Natural Resources, Massey University, Palmerston North \\ ${ }^{2}$ Institute of Food, Nutrition and Human Health, Massey University, Palmerston North
}

${ }^{1}$ BluettS@drc.co.nz

\begin{abstract}
Three lamb growth experiments were carried out at Massey University, Palmerston North, from 1995 to 1998 to evaluate the nutritive value and endophyte (Neotyphodium lolii) status of a new perennial ryegrass (Lolium perenne L.) cultivar (Aries HD). Aries HD was specifically selected for improved organic matter digestibility over summer and early autumn. Lamb liveweight gain on 'Aries HD' compared to a control cultivar 'Yatsyn 1' perennial ryegrass was higher in the summer of 1995/96 (104 vs $84 \pm 4.6 \mathrm{~g} /$ day, $\mathrm{P}=0.1028)$, similar in two consecutive summers, 1996/97 (116 vs $111 \pm 5.1$ g/day, $\mathrm{P}=0.6542$ ), and 1997/98 (71 vs 73 g/day \pm $10.6 \mathrm{~g} / \mathrm{day}, \mathrm{P}=0.7350$ ). The nutritive value (invitro organic matter digestibility, neutral detergent fibre and nitrogen content) of Aries HD and Yatsyn 1 pastures was similar. Lambs grazing Yatsyn 1 were more severely affected by ryegrass staggers than lambs grazing Aries HD, although the concentrations of lolitrem B in grazed herbage were similar. The concentration of ergovaline in Aries HD in association with endophyte was about half that in Yatsyn 1 in association with endophyte. Ergovaline may have acted synergistically to increase the toxicity of lolitrem B and the severity of staggers in lambs grazing Yatsyn 1 pastures. There was some indication that heat stress symptoms were more severe in lambs forced to graze lower into the sward. The effect of management and alkaloid concentration is likely to have a larger impact on lamb performance than small differences in nutritive value between cultivars of highendophyte perennial ryegrass.
\end{abstract}

Keywords: alkaloids, animal performance, Aries HD, endophyte, heat stress, Lolium perenne, Neotyphodium lolii, perennial ryegrass, ryegrass staggers, Yatsyn 1

\section{Introduction}

Liveweight change in sheep grazing perennial ryegrass pastures reflects the effects of ryegrass cultivar and endophyte, encompassing many interrelated effects such as ryegrass staggers, alkaloid concentrations, heat stress and faecal scouring (Fletcher \& Sutherland 1993b). The perennial ryegrass genotype or cultivar can influence the presence and quantity of alkaloids produced, and subsequent animal responses (Davies et al. 1993; Fletcher et al. 1991; Fletcher \& Sutherland 1993 a \& b). This effect may relate to differences in the vigour of endophyte growth within the plant, or to a specific regulatory effect of the plant on endophyte alkaloid metabolism (Davies et al. 1993). As a consequence specific cultivar/endophyte associations can be identified by their alkaloid profiles (Barker et al. 1993; Powell et al. 1993a). The presence of endophyte can lead to misinterpretation of both plant and animal production data from cultivar comparisons of perennial ryegrass if the endophyte status is not known (Fletcher et al. 1996; van Heeswijck \& McDonald 1992). In addition, concentrations of alkaloids are subject to wide variations due to seasonal and environmental factors (Powell et al. 1993b; Woodburn et al. 1993). It is therefore important that new endophyte strains are tested in a wide range of cultivars and in different environments or localities (Latch 1994; Siegel 1993). Care must be taken when extrapolating results from one site to another, from one year to another, and to other cultivars (van Heeswijck \& McDonald 1992).

This paper reviews three field experiments evaluating the performance of weaned lambs grazing two cultivars of perennial ryegrass over three summers in the Manawatu. Information is presented on the incidence and severity of ryegrass staggers and heat stress, and how they are related to the concentration of alkaloids produced by these two ryegrass/endophyte associations. Information on pasture and animal production from Experiments 1 and 2 has previously been published (Bluett et al. 1997; Bluett et al. 1999 a \& b). Experiment 3 will be reported in more detail in a subsequent paper.

\section{Materials and methods}

\section{Experiments}

The first two experiments (Table 1) were conducted on clover-free swards of Aries HD and Yatsyn 1 perennial ryegrass established in the autumn of 1995 . There were 
three replicate plots of each cultivar ( $0.33 \mathrm{ha})$, arranged in a randomised block design, and initially stocked with 8 Romney lambs/plot (24 lambs/ha). Lambs were allocated to plots balanced for initial liveweight and sex. Lambs were drenched monthly with Ivomec (ivomectin; Merk, Sharp and Dohme, NZ Ltd) and dipped with Vetrazin (cyromazine; Ciba-Geigy, NZ Ltd). Swards were continuously stocked with lambs to maintain a mean sward surface height of $6 \mathrm{~cm}$. Sprinkler irrigation was used in March 1996 (Experiment 1), and during December to February 1997 (Experiment 2). Two applications of the herbicide Versatill (clopyralid amine; Dow Elanco NZ Ltd) were applied at 1.5 1/ha to eliminate broadleaf weeds and white clover in Experiment 1.

The third experiment (Table 1) was conducted on clover-free swards of Aries HD and Yatsyn 1 established in the autumn of 1997. There were six replicate plots ( $0.2 \mathrm{ha}$ ) of each cultivar arranged in a randomised block design. The herbicide Tordon 50-D (picloram and 2, 4D; Dow Elanco, NZ Ltd) was applied at 4 1/ha to control broadleaf weeds, and Nortron (Ethofumesate; BASF, NZ Ltd) at 4 1/ha to control Pоа апnиа. The experiment was designed as a $2 \times 2$ factorial, with two cultivars and two grazing sequences. Two groups of Romney $\times$ Suffolk lambs (15 lambs/group) were rotationally grazed on each cultivar in a leader/follower sequence. Lambs were allocated to groups balanced for initial liveweight and sex. It was anticipated that the leader lambs would test the nutritive value of the pasture, while the follower lambs would be forced to graze into the base of the sward possessing the greatest potential for endophyte toxicity. The total fertiliser applied in each experiment is given in Table 1.

\section{Measurements}

Lamb performance: Lamb unfasted liveweight was recorded at fortnightly intervals. Lambs in Experiments 1 and 2 were slaughtered on 30 April 1996 and 25 March 1997, respectively, to record carcass weight. Initial carcass weight of the experimental lambs was predicted from regression analysis based on the 10 lambs slaughtered at the beginning of each experiment, and the carcass weight gains calculated by difference. Lambs were shorn one week before slaughter and the greasy wool weighed, and the wool yield (clean weight/greasy weight) determined (Min et al. 1998). Experiment 3 was concluded on 9 March due to the severity of ryegrass staggers and consequently, lambs were not shorn or slaughtered.
Ryegrass staggers: The incidence of ryegrass staggers was recorded as the percentage of lambs showing clinical staggers, and the data were analysed using a chi-square test (Little \& Hills 1978). In Experiment 3 lambs were scored weekly for the severity of staggers on a $0-5$ scale $(0=$ no visible symptoms; $5=$ unable to walk from the paddock, Keogh 1973). Lambs unable to walk to weighing were transported.

Faecal contamination: In Experiment 3 lambs were visually assessed fortnightly during weighing for faecal dags on a 0 (no dags) to 5 (severe dags) scale. Faecal moisture percentage was also assessed in January and February. On each occasion a faecal grab sample from each lamb was collected in a plastic pot and weighed. Samples were then dried at $80^{\circ} \mathrm{C}$ for 72 hours before weighing, and faecal moisture percentage calculated.

Heat stress: During Experiment 2 rectal temperature was recorded three times in February. Blood samples were also drawn on 3 and 7 February by jugular venipuncture into EDTA vacutainers, and were assayed for serum prolactin using the radioimmunoassay technique (Kirkwood et al. 1984). Rectal temperatures and blood samples were taken from lambs while they were in holding yards in the field. On six occasions during Experiment 3, lambs were housed in an enclosed shed to monitor heat stress symptoms (16 January to 17 February). All lambs were brought to the shed and groups of twelve lambs at a time were randomly chosen and restrained in herringbone-type bails during sampling. Ambient temperature inside the shed was recorded every half-hour. Rectal temperature was recorded using digital clinical thermometers. Respiration rates were measured by counting the number of respirations in 30 seconds using a timer with an audible alarm. Blood samples were drawn on 3, 4, 11 and 13 February and assayed for serum prolactin concentration.

Endophyte alkaloid concentration: Herbage samples cut to ground level were collected monthly from each plot in Experiments 1 and 2, and before grazing in Experiment 3, for determination of lolitrem B, ergovaline and peramine concentration by HPLC (Barker et al. 
1993). Herbage samples were stored at $-20^{\circ} \mathrm{C}$, freeze dried and ground to pass a $1 \mathrm{~mm}$ mesh diameter sieve before laboratory analysis.

\section{Statistical analysis}

Analyses of variance and repeated measures analyses were used to compare treatment means in Experiments 1 and 2, using the General Linear Models (GLM) procedure of SAS (SAS Institute Inc. 1988). All statistical analyses were based on plot mean values with three replicates. Animal performance was calculated using data from core group animals, and least square means analysis was used where numbers were unbalanced.

Analyses of variance were used to compare treatment means in Experiment 3 . The model was a $2 \times$ 2 factorial design, with two perennial ryegrass cultivars (Aries HD and Yatsyn 1) and two grazing sequences (leaders and followers). Individual lambs were treated as replicates while recognising the lack of independence within group, because all lambs grazed all replicate blocks in rotation. Alkaloid concentration was compared using sample dates as replicates.

\section{Results}

\section{Experiment 1}

Mean herbage mass, sward height, botanical composition and nutritive value were similar for Aries HD and Yatsyn 1 pastures (Bluett et al. 1997). The proportion of tillers infected with endophyte was over $90 \%$ in both cultivars. Aries HD lambs had a $24 \%$ greater liveweight gain and 32\% greater carcass weight gain than Yatsyn 1 lambs (Table 2). Ryegrass staggers was detected from late January until early March (Figure 1). Incidence of staggers among Yatsyn 1 lambs was nearly double that of lambs grazing Aries HD (Table 2). Lolitrem B concentration did not differ between cultivars (Table 3 and Figure 2). Ergovaline concentrations in Aries HD pasture samples were consistently half those of Yatsyn 1 samples (Table 3 and Figure 3). Concentration of peramine was lower in Aries HD than in Yatsyn 1 pastures (Table 3 and Figure 4).
Table 2 Liveweight gain, clean wool weight, carcass weight gain and incidence of staggers (\% of lambs with clinical staggers over period when lambs were observed staggering) of lambs grazed on two cultivars of perennial ryegrass in Experiments 1 and 2.

\begin{tabular}{lcccc}
\hline & Aries HD Yatsyn 1 & SEM & $\mathrm{P}$ \\
\hline Experiment 1 & & & & \\
Liveweight gain $(\mathrm{g} / \mathrm{h} / \mathrm{d})$ & 104 & 84 & 4.6 & 0.1028 \\
Clean wool weight $(\mathrm{kg})$ & 1.6 & 1.6 & 0.07 & 0.4580 \\
Carcass weight gain $(\mathrm{g} / \mathrm{h} / \mathrm{d})$ & 45 & 34 & 2.7 & 0.0054 \\
Incidence of staggers $(\%)$ & 15 & 29 & na & 0.0271 \\
Experiment 2 & & & & \\
Liveweight gain $(\mathrm{g} / \mathrm{h} / \mathrm{d})$ & 116 & 111 & 5.1 & 0.6542 \\
Clean wool weight $(\mathrm{kg})$ & 1.5 & 1.4 & 0.15 & 0.5535 \\
Carcass weight gain $(\mathrm{g} / \mathrm{h} / \mathrm{d})$ & 40 & 38 & 2.2 & 0.6924 \\
Incidence of staggers $(\%)$ & 0 & 9 & na & 0.1087 \\
\hline
\end{tabular}

Figure 1: The percentage of lambs showing clinical staggers in Aries HD and Yatsyn 1 pastures in Experiment 1, 2, and 3 at Massey University. The percentages shown for Experiment 3 are leader lambs only.

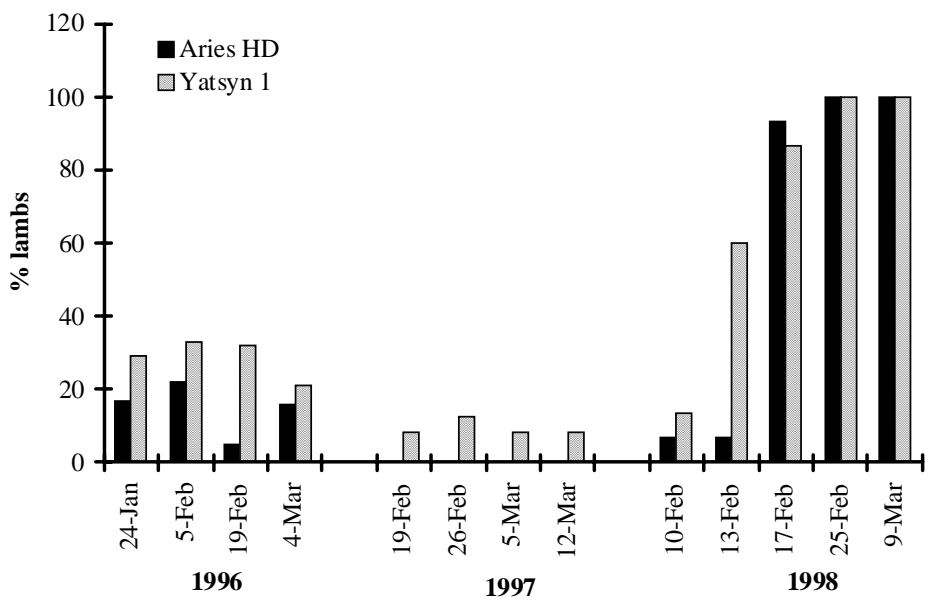

Table 3 Mean endophyte alkaloid concentration (ppm) of two perennial ryegrass cultivars in Experiments 1 (17 December to 19 April 1996: mean of 5 dates) and 2 (30 December to 27 March 1997: mean of 4 dates). Minimum and maximum concentrations recorded over the summer are shown in brackets.

\begin{tabular}{lcccc}
\hline & Aries HD & Yatsyn 1 & SEM & $\mathrm{P}$ \\
\hline Experiment 1 & & & & \\
Lolitrem B & $0.95(0.36-1.63)$ & $0.97(0.43-1.56)$ & 0.197 & 0.8875 \\
Ergovaline & $0.23(0.20-0.33)$ & $0.42(0.40-0.47)$ & 0.042 & 0.0258 \\
Peramine & $11.85(9.03-17.17)$ & $15.92(15.23-17.9)$ & 0.992 & 0.0258 \\
Experiment 2 & & & & \\
Lolitrem B & $0.97(0.70-1.16)$ & $0.98(0.53-1.36)$ & 0.159 & 0.9475 \\
Ergovaline & $0.00(0.00-0.01)$ & $0.06(0.00-0.09)$ & 0.024 & 0.0848 \\
Peramine & $9.98(7.4-10.6)$ & $14.23(7.6-16.03)$ & 3.608 & 0.2377 \\
\hline
\end{tabular}




\section{Experiment 2}

Sward conditions and nutritive value estimates were again similar for Aries HD and Yatsyn 1 pastures (Bluett et al. 1999b). The proportion of tillers infected with endophyte was greater than $80 \%$ in both cultivars. There was no difference in performance between lambs grazing Aries HD and Yatsyn 1 pasture (Table 2). Incidence of ryegrass staggers was low with $9 \%$ of Yatsyn 1 lambs (mean severity score of 3.0) and none of Aries HD lambs being affected from late February to early March (Figure 1). Lolitrem B and peramine concentration did not differ between cultivars (Table 3, Figures 2 and 4). Ergovaline levels were barely detectable over this experiment (Table 3 and Figure 3 ). There were no differences in rectal temperature (mean of $40.1^{\circ} \mathrm{C}$ ) or serum prolactin concentration (mean of $69 \mathrm{ng} / \mathrm{ml}$ ) recorded in the field for lambs grazing Aries $\mathrm{HD}$ and Yatsyn 1 pastures.

\section{Experiment 3}

There were no significant interactions between cultivar and grazing management $(\mathrm{P}>0.05)$. The proportion of tillers infected with endophyte was $96 \%$ in both cultivars. Mean pregrazing sward height, herbage mass, botanical composition and nutritive value were similar between Aries HD and Yatsyn 1 cultivars (Bluett 1999). However, the leader-follower grazing regime created contrasts in sward conditions between the two managements. The pre-grazing sward height (mean for both cultivars) in leader pastures was $13.5 \mathrm{~cm}$ compared to $7.1 \mathrm{~cm}$ in follower pastures $(\mathrm{P}=0.0001)$. The post-grazing sward height (mean for both cultivars) for the leaders was $7.1 \mathrm{~cm}$ compared to $6.0 \mathrm{~cm}$ in the followers $(\mathrm{P}=0.01)$. Leader pastures contained a higher proportion of green ryegrass and were higher in invitro organic matter digestibility and lower in neutral detergent fibre content (Bluett 1999). Leader lambs had faster liveweight gains (Table 4) and were $5 \mathrm{~kg}$ heavier than follower lambs at the completion of the experiment in March. There was no difference in lamb performance between the two cultivars (Table 4). only. only.
Figure 2: Mean lolitrem B concentration (ppm) from herbage cut to ground level in Aries $\mathrm{HD}(\bullet)$ and Yatsyn $1(\square)$ pastures in Experiment 1,2 and 3 at Massey University. Concentrations shown for Experiment 3 are for leader pastures

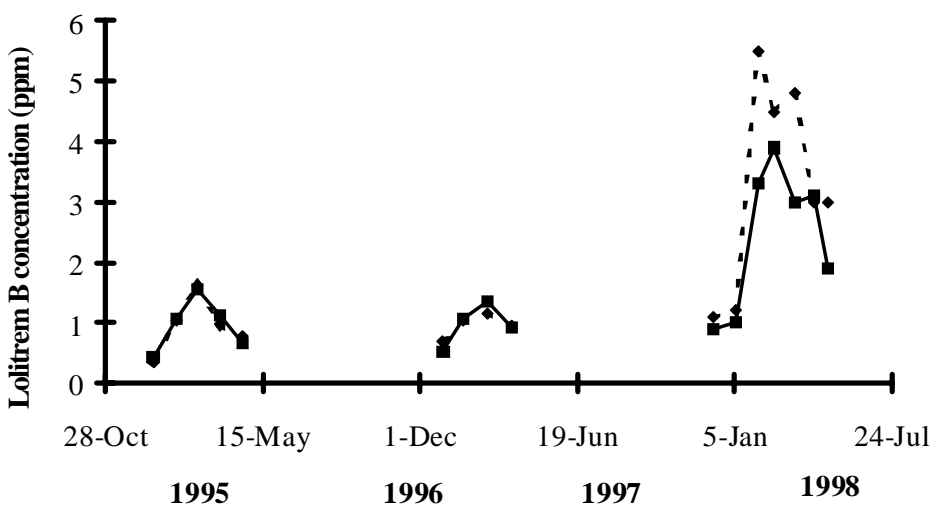

Figure 3: Mean ergovaline concentration (ppm) from herbage cut to ground level in Aries HD $(\diamond)$ and Yatsyn $1(\square)$ pastures in Experiment 1, 2 and 3 at Massey University. Concentrations shown for Experiment 3 are for leader pastures

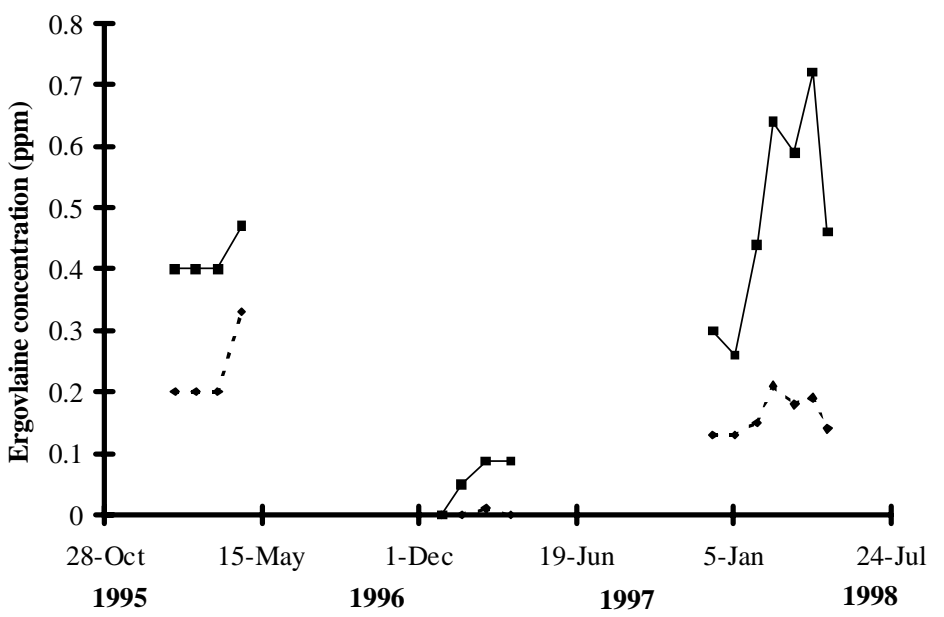

Follower lambs were the first to show symptoms of ryegrass staggers in January. In mid-February there was a sharp rise in the incidence and severity of staggers (Figures 1 and 5), coinciding with increasing levels of lolitrem B (Figure 2). There was no difference in lolitrem B or peramine concentration between cultivars (Table 5 and Figures 2 and 4). However, ergovaline concentrations in Aries HD were consistently about half those of Yatsyn 1 samples (Figure 3). By the end of February $100 \%$ of lambs had severe staggers (mean score greater than 3.0). Both cultivar and management 
Table 4 Liveweight gain, staggers score, rectal temperature, serum prolactin concentration, faecal dag score and faecal moisture percentage in Experiment 3. $\mathrm{n}$ is the number of times measurements were taken.

\begin{tabular}{|c|c|c|c|c|c|c|c|c|c|}
\hline & \multirow{2}{*}{$\begin{array}{l}\text { Measurement } \\
\text { period }\end{array}$} & \multirow[t]{2}{*}{$\mathrm{n}$} & \multicolumn{2}{|c|}{----- Leaders ------ } & \multicolumn{2}{|c|}{---- Followers ----- } & \multirow[t]{2}{*}{ SEM } & \multicolumn{2}{|c|}{ - } \\
\hline & & & Aries HD & Yatsyn 1 & Aries HD & Yatsyn 1 & & Cultivar & Management \\
\hline Liveweight gain ( g day $^{-1}$ ) & 1 Dec-9 March & 9 & 87 & 96 & 55 & 50 & 10.6 & 0.7350 & 0.0003 \\
\hline Staggers score $(0-5)$ & 10 Feb-9 March & 4 & 3.1 & 3.9 & 4.0 & 4.4 & 0.23 & 0.0091 & 0.0034 \\
\hline Rectal temperature $\left({ }^{\circ} \mathrm{C}\right)$ & 16 Jan-17 Feb & 6 & 40.1 & 40.1 & 40.1 & 40.3 & 0.07 & 0.6435 & 0.1497 \\
\hline $\begin{array}{l}\text { Respiration rate } \\
\text { (breaths/minute) }\end{array}$ & 16 Jan-17 Feb & 6 & 75.0 & 78.3 & 73.3 & 76.5 & 1.13 & 0.0010 & 0.0603 \\
\hline Serum prolactin cc. $\left(\mathrm{ng} \mathrm{ml}^{-1}\right)$ & 3 Feb-13 Feb & 4 & 199 & 164 & 126 & 114 & 18.0 & 0.1811 & 0.0012 \\
\hline Faecal dag score (0-5) & 6 Jan-9 March & 5 & 1.8 & 1.6 & 1.1 & 1.0 & 0.33 & 0.6946 & 0.0341 \\
\hline Faecal moisture (\%) & 30 Jan-13 Feb & 2 & 75 & 74 & 74 & 76 & 1.7 & 0.9756 & 0.7780 \\
\hline
\end{tabular}

Table 5 Mean endophyte alkaloid concentration (ppm) in Experiment 3 (9 December to 31 March 1998). Minimum and maximum concentrations recorded over the summer (mean of 5 dates) are shown in brackets.

\begin{tabular}{|c|c|c|c|c|c|c|c|}
\hline & \multicolumn{2}{|c|}{------- Leaders -------- } & \multicolumn{2}{|c|}{------ Followers ------- } & \multirow[t]{2}{*}{ SEM } & \multirow{2}{*}{ Cultivar } & \multirow{2}{*}{$\begin{array}{l}P \text { - ----------- } \\
\text { Management }\end{array}$} \\
\hline & Aries HD & Yatsyn 1 & Aries HD & Yatsyn 1 & & & \\
\hline Lolitrem B & $\begin{array}{c}3.42 \\
(1.1-5.5)\end{array}$ & $\begin{array}{c}2.42 \\
(0.9-3.9)\end{array}$ & $\begin{array}{c}3.60 \\
(1.3-6.0)\end{array}$ & $\begin{array}{c}2.80 \\
(1.3-4.1)\end{array}$ & 0.769 & 0.2531 & 0.7171 \\
\hline Ergovaline & $\begin{array}{c}0.16 \\
(0.13-0.21)\end{array}$ & $\begin{array}{c}0.45 \\
(0.30-0.72)\end{array}$ & $\begin{array}{c}0.25 \\
(0.16-0.38)\end{array}$ & $\begin{array}{c}0.53 \\
0.38-0.67)\end{array}$ & 0.050 & 0.0001 & 0.1136 \\
\hline Peramine & $\begin{array}{c}11.12 \\
(7.7-19.1)\end{array}$ & $\begin{array}{c}14.43 \\
(8.1-22.8)\end{array}$ & $\begin{array}{c}9.94 \\
(4.8-14.4)\end{array}$ & $\begin{array}{c}12.76 \\
(8.3-16.9)\end{array}$ & 1.790 & 0.1077 & 0.4423 \\
\hline
\end{tabular}

(Table 4) affected staggers severity score. Serum prolactin concentration and respiration rates were higher in follower than in leader lambs. Respiration rate was higher in lambs grazing Yatsyn 1 (Table 4). Cultivar or management did not affect lamb rectal temperature. The mean ambient temperature when blood samples were drawn was $32^{\circ} \mathrm{C}$ and it was $29^{\circ} \mathrm{C}$ on the days when respiration rate and rectal temperatures were recorded. Faecal dag score was higher in leader lambs than follower lambs, but there was no difference in faecal moisture percentage (Table 4).

\section{Discussion}

The three experiments covered a range of environmental conditions that maximised the opportunity to investigate the effects of endophyte. The alkaloid challenge imposed on the lambs ranged from minimal (Experiment 2) to moderate (Experiment 1) to extreme (Experiment 3) and was the major determinant of the animal responses. The nutritive value (in-vitro organic matter digestibility, neutral detergent fibre and nitrogen content) of Aries HD and Yatsyn 1 were similar only.
Figure 4: Mean peramine concentration (ppm) from herbage cut to ground level in Aries HD $(\bullet)$ and Yatsyn $1(\square)$ pastures in Experiment 1, 2 and 3 at Massey University. Concentrations shown for Experiment 3 are for leader pastures

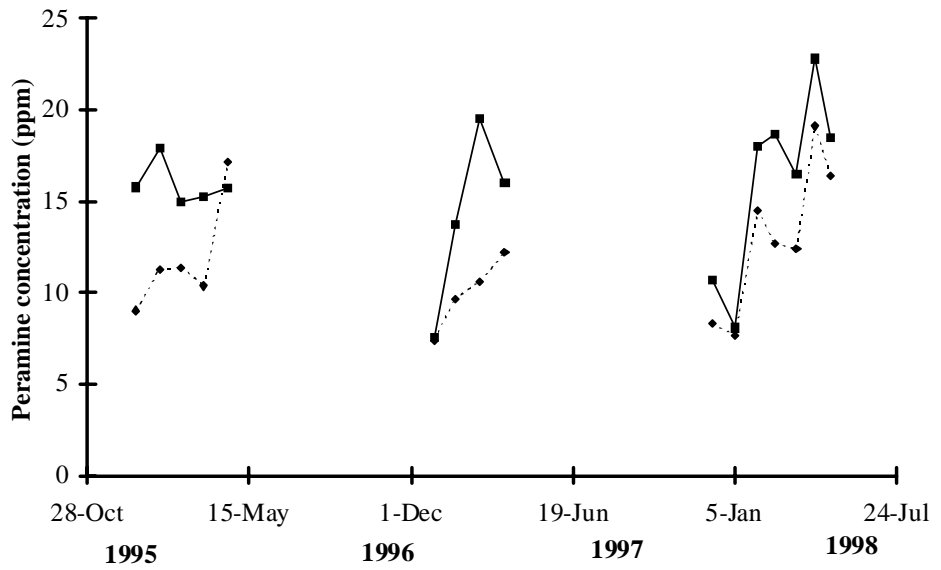

in herbage samples cut to ground level, from plucked samples and from cage cut samples under both continuous stocking and rotational grazing management (Bluett 1999).

The better animal performance of lambs on Aries HD in Experiment 1 (Table 2) could not be attributed to any difference in herbage nutritive value, but was related to differences in alkaloid concentrations and severity of 
ryegrass staggers. In Experiment 2 there was no difference in lamb performance (Table 2) reflecting the similar alkaloid concentrations and nutritive value estimates between the two cultivars. Lamb rectal temperatures and serum prolactin concentrations were similar between cultivars. However, ambient temperatures did not exceed $22^{\circ} \mathrm{C}$ on measurement days and ergovaline levels were undetectable, so it was unlikely that lambs were affected by heat stress in this experiment. It was concluded that lambs were faced with a lower alkaloid challenge in Experiment 2 than in Experiment 1 , confirmed by the low incidence of ryegrass staggers.

Lambs in Experiment 3 were severely affected by ryegrass staggers, with peak lolitrem $B$ concentrations almost three times higher than in the previous two summers (Figure 2). There was an effect of management on performance, with leader lambs gaining $92 \mathrm{~g} / \mathrm{day}$ compared to only $53 \mathrm{~g} / \mathrm{day}$ for lambs grazing follower swards. The successive grazing regime forced follower lambs to consume more stem and dead leaf material left behind by the leader lambs. Follower lambs were also more severely affected by ryegrass staggers, possibly reflecting a higher intake of tremorgens. Pownall et al. (1993) grazed endophyte-infected hybrid ryegrass successively by four groups of lambs, and reported liveweight gains ranging from $164 \mathrm{~g} /$ day in lambs having first offer, to $28 \mathrm{~g} /$ day in those grazing the base of the pasture. In this experiment and that of Pownall et al. (1993), staggers severity was lowest and faecal dag score highest in leader lambs.

Ergovaline concentrations in Aries HD pasture were about half those in Yatsyn 1 pasture. Sheep grazing Yatsyn 1 were more severely affected by ryegrass staggers than sheep grazing Aries HD, although concentrations of lolitrem B were similar. The higher concentrations of ergovaline produced by Yatsyn 1 in association with endophyte might have acted synergistically with lolitrem $B$ to increase its toxicity and the severity of staggers in lambs grazing Yatsyn 1. Fletcher and Easton (1997) have reported that lambs grazing ryegrass with 50\% wild-type endophyte and 50\% AR6 (no lolitrem/high ergovaline) had similar levels of staggers to those grazing ryegrass with $100 \%$ wild-type endophyte, despite a $50 \%$ reduction in the concentration of lolitrem B. It is also possible that another alkaloid not measured in this study could have contributed to the difference in staggers severity. For example, concentrations of paxilline have been correlated with the incidence of staggers in the absence of lolitrem B (Fletcher et al. 1993). In addition, respiration rate which is an indicator of heat stress, was higher in lambs grazing Yatsyn 1 pastures in Experiment 3.

In Experiment 3 serum prolactin concentration was reduced in follower lambs. Prolactin is sensitive to low levels of ergovaline and can be a good indicator of intoxication with ergopeptine alkaloids including ergovaline (Fletcher \& Easton 1997). The mean concentration of ergovaline measured from herbage on offer was $28 \%$ higher in follower swards, although this difference was not significant (Table 5). Ergovaline concentrations are typically highest in basal vegetative tissue and if grazed may pose a risk to animal health (Lane et al. 1997). It can not be discerned whether the respiration rates and serum prolactin levels observed were different to normal because endophyte-free control pastures were not included to establish base levels (Fletcher \& Easton 1997). However, it is apparent that differences existed between the grazing managements and cultivar/endophyte associations. There were no significant differences in liveweight gain between Aries HD and Yatsyn 1 lambs in Experiment 3 (Table 4). It is possible that the severe and debilitating symptoms of ryegrass staggers may have masked the effects of differences in ergovaline concentration, staggers severity and heat stress between cultivars on animal performance during the period when severe staggers were observed.

\section{Conclusions}

From this series of experiments it was concluded that the differences in nutritive value between cultivars were small, and differences in lamb performance over summer 
and autumn reflected contrasts in the production and balance of endophyte alkaloids from the different cultivar/endophyte associations.

Aries HD in association with endophyte consistently produced about half the concentration of ergovaline produced by Yatsyn 1 in association with endophyte. Ergovaline may have acted synergistically to increase the toxicity of lolitrem B and the severity of staggers in lambs grazing Yatsyn 1 swards. Respiration rate was higher in lambs grazing Yatsyn 1. There was also a suggestion that heat stress symptoms were more severe in lambs forced to graze lower into the sward.

This work also highlighted the importance of assessing not only nutritive value, but the effects of the cultivar/endophyte association in animal evaluations of perennial ryegrass in New Zealand. The effect of management and alkaloid concentration is likely to have a larger impact on lamb performance than small differences in nutritive value between cultivars of highendophyte perennial ryegrass.

\section{ACKNOWLEDGEMENTS}

Wrightson Seeds Ltd, Christchurch funded this research. The authors wish to thank the staff from the Institute of Food, Nutrition and Human Health, the Institute of Natural Resources, and the Sheep and Cattle Research Unit, Massey University for their assistance. The National Institute of Arthritis, Diabetes and Digestive and Kidney Diseases (NIADDK) and the National Hormone and Pituitary Program (NHPP) are also acknowledged for providing materials for prolactin assays. AgResearch, Palmerston North is thanked for providing the alkaloid analyses.

\section{REFERERENCES}

Barker, D.J.; Davies, D.; Lane, G.A.; Latch, G.C.M.; Nott, H.M.; Tapper, B.A. 1993. Effect of water deficit on alkaloid concentrations in perennial ryegrass endophyte associations. pp. 67-71. In: Proceedings of the Second International Symposium on Acremonium/Grass Interactions.

Bluett, S.J. 1999. An evaluation of the nutritive value and endophyte status of a new perennial ryegrass (Lolium perenne) cultivar (Aries HD). pp. 161-201, 212-217. PhD thesis, Massey University.

Bluett, S.J.; Hodgson, J.; Kemp, P.D.; Barry, T.N. 1997. Animal evaluation of Aries HD perennial ryegrass selected for high digestibility. Proceedings of the New Zealand Grassland Association 59: 245-249.

Bluett, S.J.; Hodgson, J.; Kemp, P.D.; Barry, T.N. 1999a. Survival, reproductive development and density of tillers in pure swards of Aries HD and Yatsyn 1 perennial ryegrass (Lolium perenne). Proceedings of the New Zealand Grassland Association 61: 197-202.

Bluett, S.J.; Hodgson, J.; Kemp, P.D.; Barry, T.N. 1999b. Evaluation of the feeding value of Aries HD perennial ryegrass (Lolium perenne). II. Performance of weaned lambs in summer. New Zealand Journal of Agricultural Research 43: 449-458.

Davies, E.; Lane, G.A.; Latch, G.C.M.; Tapper, B.A. 1993. Alkaloid concentrations in field-grown synthetic perennial ryegrass endophyte associations. pp. 72-76. In: Proceedings of the Second International Symposium on Acremonium/Grass Interactions.

Fletcher, L.R.; Easton, H.S. 1997. The evaluation and use of endophytes for pasture improvement. pp. 209227. In: Neotyphodium/Grass Interactions. Eds. Bacon, C.W.; Hill, N.S., Plenum Press, New York \& London.

Fletcher, L.R.; Sutherland, B.L. 1993a. Flystrike and faecal contamination in lambs grazing endophyte infected ryegrass. pp. 122-124. In: Proceedings of the Second International Symposium on Acremonium/Grass Interactions.

Fletcher, L.R.; Sutherland, B.L. 1993b. Liveweight change in lambs grazing perennial ryegrass with different endophytes. pp. 125-127. In: Proceedings of the Second International Symposium on Acremonium/Grass Interactions.

Fletcher, L.R.; Popay, A.J.; Tapper, B.A. 1991. Evaluation of several lolitrem B-free endophyte/ perennial ryegrass combinations. Proceedings of the New Zealand Grassland Association 53: 215-219.

Fletcher, L.R.; Garthwaite, I.; Towers, N.R. 1993. Ryegrass staggers in the absence of lolitrem B. pp. 119-121. In: Proceedings of the Second International Symposium on Acremonium/Grass Interactions.

Fletcher, L.R.; Sutherland, B.L.; Fletcher, C.G.; Easton, H.S. 1996. The impact of endophyte toxins on the health of grazing sheep - an evolving story. Proceedings of the Second Pan Pacific Veterinary Conference-Sheep: 31-42.

Keogh, R.G. 1973. Induction and prevention of ryegrass staggers in grazing sheep. New Zealand Journal of Experimental Agriculture 1: 55-57.

Kirkwood, R.N.; Lapwood, D.R.; Smith, W.C.; Anderson, I.L. 1984. Plasma concentrations of LH, prolactin, oestradiol-17B and progesterone in sows weaned after lactation for 10 or 35 days. Journal of Reproduction and Fertility 70: 95-102.

Lane, G.A.; Ball, O.J.-P.; Davies, E.; Davidson, C. 1997. Ergovaline distribution in perennial ryegrass naturally infected with endophyte. pp. 65-67. In: Neotyphodium/Grass Interactions. Eds. Bacon, C.W.; Hill, N.S. Plenum Press, New York \& London. 
Latch, G.C.M. 1994. Influence of Acremonium endophytes on perennial grass improvement. New Zealand Journal of Agricultural Research 38: 311318.

Little, T.M.; Hills, F.J. 1978. Analysis of counts. pp. 267-294. In: Agricultural Experimentation: Design and Analysis. John Wiley \& Sons, Inc., USA.

Min, B.R.; Barry, T.N.; McNabb, W.C.; Kemp, P.D. 1998. Effect of condensed tannins on the production of wool and on its processing characteristics in sheep grazing Lotus corniculatus. Australian Journal of Agricultural Research 49: 597-605.

Powell, R.G.; TePaske, M.R.; Plattner, R.D.; Petroski, R.J. 1993a. Recent progress in the chemistry of grass/fungal interactions. p. 93. In: Proceedings of the Second International Symposium on Acremonium/Grass Interactions.

Powell, R.G.; TePaske, M.R.; Plattner, R.D.; Petroski, R.J. 1993b. Recent progress in the chemistry of grass/fungal interactions. pp. 85-57. In: Proceedings of the Second International Symposium on Acremonium/Grass Interactions: Plenary Papers.
Pownall, D.B.; Lucas, R.J.; Familton, A.S.; Love, B.G.; Hines, S.E.; Fletcher, L.R. 1993. The relationship between staggers and diarrhoea in lambs grazing different components of endophyte-infected ryegrass. Proceedings of the New Zealand Society of Animal Production 53: 19-22.

SAS, 1988. SAS user's guide, release 6.03 edition. Statistical Analysis System Institute. Cary, North Carolina, United States of America.

Siegel, M.R. 1993. Acremonium endophytes: our current state of knowledge and future directions for research. pp. 301-321. In: Agriculture, Ecosytems and Environment 44. Elsevier Science Publishers, Amsterdam.

Woodburn, O.J.; Walsh, J.R.; Foot, J.Z.; Heazlewood, P.G. 1993. Seasonal ergovaline concentrations in perennial ryegrass cultivars of differing endophyte status. pp. 100-102. In: Proceedings of the Second International Symposium on Acremonium/Grass Interactions.

van Heeswijck, R.; McDonald, G. 1992. Acremonium endophytes in perennial ryegrass and other pasture grasses in Australia and New Zealand. Australian Journal of Agricultural Research 43: 1683-1709. 